\title{
ELLICE MARTIN HORSBURGH

\author{
M.A., D.SC., A.M.INST.C.E., F.R.S.E.
}

By E. T. Whittaker.

Dr Ellice Martin Horsburgh was for thirty-two years in charge of the department of Technical Mathematics in the University of Edinburgh, and is gratefully remembered by many generations of former engineering students as a most inspiring lecturer and generous friend.

He was born at Kelso in 1870 , the youngest son of the Rev. Andrew Horsburgh, for many years a chaplain in India, and his wife Ellen Sarah Vost. At the time of his death, he and his brother were the last survivors of that branch of the Horsburghs of Horsburgh in Peeblesshire who migrated to South Fife in the latter part of the sixteenth century and settled in the neighbourhood of Pittenweem.

Educated at the Collegiate School in Charlotte Square, Edinburgh, he followed the family tradition in deciding to go to India, and was sent to the famous London coaches, Wren and Gurney, to be prepared for the Open Competition for the Indian Civil Service. His health broke down, however, and his medical advisers ordered a voyage to Australia in a sailing ship, during which he mastered the science of navigation. Arriving in Melbourne at the time of the financial panic-the aftermath of the land boom-he was in Australia during the great Coolgardie rush, and had interesting experiences as a gold miner in small goldfields in central Victoria. After an absence of two years he returned to Edinburgh and graduated M.A. and B.Sc. in Engineering in 1897, and B.Sc. in Mathematics and Natural Philosophy in 1899, and served his apprenticeship as a Civil Engineer, becoming Assoc.M.Inst.C.E. in 1900. His interests, however, lay chiefly in teaching, and he obtained appointments as lecturer in Electrical Engineering in Leith Technical College, and lecturer in mathematics and mechanics to the advanced evening classes at the Heriot-Watt College.

In 1903 the Edinburgh University Court resolved to institute special courses in mathematics for engineering students, and appointed Mr Horsburgh as the first lecturer. Fresh classes were instituted from time to time, and when the rank of Reader was instituted in 1920 he was appointed to it. In 1924 he was made a member of 
Senatus. For many years his spare time was spent in the Research Laboratory of Messrs Brunton's Wire Mills at Musselburgh, and in 1918 he received the degree of D.So. for a thesis entitled "Researches on the Structure, Strength, and Commercial Testing of Steel Wire Ropes."

Among his original papers may be mentioned:-

Proof of a fundamental relation in the theory of bending (Proc. Edinburgh Math. Soc., 1911).

A simple linkage for describing equal areas (ibid. 1912).

An approximate formula for the length of an arc of a suspended rope (ibid. 1917).

Calculating Machines (Proc. Inst. Eng. and Shipb. in Scotland, 1919).

The fracture of wire in steel ropes (Engineering, 1921).

The alternating torsion of rope-wire (Engineering, 1922).

A continuous process for root extraction by calculating machines (Proc. Inst. Eng. and Shipb. in Scotland, 1922).

Large-grained steel wire and a comparison with rope wire (ibid., 1926).

He was Editor of the volume of 350 pages published in connection with the Napier Tercentenary Exhibition in 1914, and wrote many of the articles in it: and was also the author of papers on subjects not connected with mathematics or engineering, notably in the Geographical Magazine, where he maintained that the Thule of Tacitus should be identified with Fair Island. He was an authority on numismatics, and an expert photographer; for many years he sailed a small yacht on the Clyde, and he was a good shot and a skilled gardener.

To the Edinburgh Mathematical Society he gave devoted service for a long term of years as Honorary Treasurer, creating a substantial reserve fund from excess of income over expenditure. $\mathrm{He}$ was repeatedly invited to accept the Presidency, but declined the honour.

When at the end of the session 1934-35 he reached the normal age-limit for retirement, the University Court invited him to continue in office; during the long Vacation, however, it became evident that his health would be unequal to the strain, and he sent in his resignation, which was regretfully accepted. He died on 28th December 1935 at his house in Granville Terrace, Edinburgh, and was buried at Dirleton in East Lothian.

Dr Horsburgh married in 1920 Miss Helen Howden Ferme, by whom he is survived. 